\title{
PENGARUH KEPEMIMPINAN KEPALA SEKOLAH DAN BIAYA PENDIDIKAN TERHADAP KUALITAS PROSES BELAJAR MENGAJAR DAN DAMPAKNYA DENGAN KOMPETENSI LULUSAN SMK DI KABUPATEN GUNUNGKIDUL
}

\author{
Sri Yayuk ${ }^{1 *}$, Sugiyono ${ }^{2}$ \\ 1SMK Negeri 1 Wonosari, 2Universitas Negeri Yogyakarta \\ 1Jl. Veteran, Madusari, Wonosari, Gunung Kidul, 55813, Yogyakarta, Indonesia \\ 2Jl. Colombo No. 1, Depok, Sleman 55281, Yogyakarta, Indonesia \\ yevitri@yahoo.com, sugiyono_1953@yahoo.com
}

\begin{abstract}
Abstrak
Tujuan penelitian ini untuk mengetahui pengaruh kepemimpinan kepala sekolah dan biaya pendidikan terhadap kualitas proses belajar mengajar dan dampaknya dengan kompetensi lulusan SMK. Penelitian ini merupakan penelitian Ex Post Facto dengan menggunakan pendekatan kuantitatif. Penelitian dilaksanakan di sembilan SMK di Gunungkidul, dengan responden 210 guru. Pengumpulan data dalam penelitian ini menggunakan kuesioner. Analisis data dalam penelitian ini menggunakan analisis regresi dan analisis jalur (Path Analysis). Hasil penelitian menunjukkan bahwa: (1) struktur pengaruh yang mempengaruhi kompetensi lulusan tidak terbukti secara empiris; (2) Tidak terdapat pengaruh langsung kepemimpinan kepala sekolah dengan kompetensi lulusan dan terdapat pengaruh tidak langsung kepemimpinan kepala sekolah dengan kompetensi lulusan melalui kualitas proses belajar mengajar yaitu sebesar 0,059; (3) Terdapat pengaruh langsung sebesar 0,221 dan tidak langsung sebesar 0,096 biaya pendidikan dengan kompetensi lulusan; (4) pengaruh kepemimpinan kepala sekolah, biaya pendidikan dan kualitas proses belajar mengajar terhadap kompetensi lulusan masing-masing sebesar 2,6\%, 10,6\%, 13,0\%; (5) pengaruh kepemimpinan kepala sekolah dan biaya pendidikan terhadap kualitas proses belajar mengajar sebesar $21 \%$ dan pengaruh setiap variabel sebesar $8,7 \%, 16,8 \%$. dan $5,9 \%$.

Kata kunci: kepemimpinan kepala sekolah, biaya pendidikan, kualitas proses belajar mengajar, kompetensi lulusan

\section{THE EFFECT OF PRINCIPAL LEADERSHIP AND EDUCATION COSTS ON THE QUALITY OF THE TEACHING AND LEARNING PROCESS AND THE SUBSEQUENT IMPACT ON COMPETENCE OF VOCATIONAL SCHOOL GRADUATES IN GUNUNGKIDUL REGENCY}

\begin{abstract}
The purpose of this study was to determine the effect of principals' leadership and education costs on the quality of teaching and learning processes and their impact on the competence of vocational school graduates. This study is an Ex Post Facto study using a quantitative approach. The study was conducted in 9 Vocational Schools in Gunungkidul, with 210 teachers as respondents. Data collection in this study uses a questionnaire. Testing the hypothesis with Path Analysis. The results of the study show that: (1) the structure of influence that influences graduate competency is not empirically proven; (2) There is no direct influence of the principal's leadership with graduate competency and there is an indirect influence of the principal's leadership with graduate competence through the quality of the teaching and learning process which is equal to 0.059; (3) There is a direct effect of 0.221 and indirectly by 0.096 costs of education with graduate competencies; (4) the influence of principals' leadership, education costs and the quality of the teaching and learning process on graduate competencies of $2.6 \%, 10.6 \%$, $13.0 \%$ respectively; (5) the influence of principals' leadership and education costs on the quality of teaching and learning processes is $21 \%$ and the effect of each variable is $8.7 \%, 16.8 \%$ and.5.9\%.
\end{abstract}

Keywords: principal leadership, education costs, quality of teaching and learning processes, graduate competency

Permalink/DOI: http://dx.doi.org/10.21831/amp.v7i1.23758 


\section{Pendahuluan}

Pasar bebas ASEAN Economy Community (AEC) merupakan tantangan dan peluang bagi Indonesia untuk dapat hidup sejajar dengan negara-negara lain yang lebih maju. Peningkatan daya saing ini dimulai dari penyiapan Sumber Daya Manusia (SDM) yang berkualitas, agar SDM yang dimiliki mempunyai keahlian dan keterampilan, terutama bagi tenaga kerja dalam jumlah yang memadai dalam segala tingkatan. Sesuai pernyataan Kajian Bank Dunia yang dirilis oleh Republika.co.id (Damhuri, 2017) bahwa kunci keberhasilan pembangunan suatu negara adalah pembangunan kualitas SDM sehingga tersedia penduduk yang terdidik dalam jumlah, jenis, dan tingkat yang memadahi, dengan menempatkan pembangunan pendidikan menjadi prioritas utama dalam pembangunan nasional (Damhuri, 2017).

Pendidikan dilaksanakan untuk meningkatkan potensi manusia lewat proses pembelajaran yang ada di dalamnya. Hal ini tertuang dalam Undang-Undang Sistem Pendidikan Nasional (USPN) No. 20 Tahun 2003 (Presiden Republik Indonesia, 2003). Berdasarkan data dari berbagai survei internasional, kualitas hasil pendidikan Indonesia masih relatif rendah dan tertinggal oleh negara-negara lain, termasuk sesama negara ASEAN. Laporan program pembangunan PBB dalam The United Nations Development Programme (UNDP) pada tahun 2015 menyajikan laporan Indeks Pembangunan Manusia (IPM) dirilis pada tanggal 14 Desember 2015, Indonesia menempati peringkat 110 dari 188 negara dengan nilai 69,55 (United Nations Development Programme, 2015, p. 48).

Permasalahan pendidikan di Indonesia sesuai artikel dari CNN Indonesia yaitu rendahnya kualitas sarana fisik, rendahnya kualitas guru, rendahnya kesejahteraan gu$\mathrm{ru}$, rendahnya prestasi siswa, rendahnya kesempatan pemerataan pendidikan, rendahnya relevansi pendidikan dengan kebutuhan, dan mahalnya biaya pendidikan. Jumlah pengangguran terdidik yang dilaporkan oleh Badan Pusat Statistik (BPS) Indonesia selama tahun 2016 sampai dengan tahun
2018 menunjukkan bahwa angka Tingkat Pengangguran Terbuka (TPT) yang tertinggi dari Februari 2016 sampai dengan Februari 2018 adalah pada tingkat SMK diantara tingkat pendidikan lainnya. Seperti halnya tingkat pengangguran di D.I. Yogyakarta, data bulan Februari 2018 SMK menyumbang penganggur terbanyak setelah SMA yaitu 3,23\% (Badan Pusat Statistik, 2018).

Permasalahan-permasalahan pendidikan seperti diuraikan di atas dapat teratasi dengan pembangunan pendidikan, dengan harapan pendidikan di Indonesia bangkit dari keterpurukan dan mutu pendidikan di Indonesia sejajar dengan mutu pendidikan negara-negara yang sekarang memiliki mutu tinggi. Data prestasi atau hasil belajar siswa di DIY dari tahun 2014 sampai dengan 2017 menunjukkan bahwa prestasi siswa dari tahun 2014 hingga 2017 mengalami penurunan, artinya kualitas pendidikan di DIY belum menunjukkan hasil yang memuaskan. Oleh sebab itu, untuk mengatasi hal tersebut pembangunan di bidang pendidikan perlu ditingkatkan.

Informasi yang dirilis (Putri, 2018) student.cnnindonesia.com pada tanggal 3 Januari 2018 menjelaskan bahwa penyebab rendahnya mutu pendidikan di Indonesia antara lain adalah masalah efektifitas, efisiensi dan standar dasar pengajaran. Dari hasil monitoring pengawas dan hasil pengamatan pengawasan SMK Kabupaten Gunungkidul dan wawancara dengan Wakil Kepala Sekolah Urusan Kurikulum di beberapa SMK menyatakan masih ada beberapa guru yang belum menyusun perencanaan sebelum melaksanakan pembelajaran, proses pembelajaran belum sesuai dengan rencana yang dibuat, beberapa guru masih mendominasi pembelajaran dengan metode ceramah, dan kurang efektifnya guru menggunakan waktu dalam proses belajarnya, karena masih ada guru yang terlambat memulai pelajaran dan lebih cepat mengakhiri pelajaran. Keadaan ini menunjukan bahwa kualitas proses pembelajaran belum sesuai dengan standar yang ditetapkan. Pencapaian mutu sesuai yang diharapkan baik proses pembelajaran maupun mutu lulusannya, biaya pendidikan merupakan unsur 
yang penting dalam pendidikan (Martin \& Fuad, 2014, pp. 1-2).

Pemerintah pusat dan daerah terus meningkatan biaya pendidikan melalui dana BOS, BSM, BOSDA, dana alokasi khusus dari Kabupaten. Akan tetapi program tersebut perlu di evaluasi, karena kenyataannya masih banyak anak miskin yang susah masuk sekolah. Pendistribusian bantuan yang lambat, alokasi yang tidak akurat, dan juga penyelewengan dana turut menyelimuti implementasi program tersebut (Fadhilah \& Hermawan, 2017).

Hal tersebut dapat diatasi jika kepemimpinan pendidikan dapat menjalankan perannya dengan baik dalam upaya peningkatan mutu pendidikan. Pernyataan di atas diperkuat oleh Wahyudin (2014, p. 202) yang menyatakan bahwa kepala sekolah dituntut memiliki kemampuan manajemen dan kepemimpinan yang tangguh agar mampu mengambil keputusan dan prakasa untuk menentukan mutu sekolah. Kepala sekolah harus dapat memastikan proses pembelajaran berlangsung dengan efektif. Oleh karena itu kepala sekolah juga harus dapat mendorong guru-gurunnya menjadi guru yang efektif yang dapat mengelola pembelajaran dengan profesional sehingga hasil proses pembelajaran memiliki kualitas yang tinggi (Priansa, 2014, p. 26).

Uraian di atas memberikan gambaran bahwa kepemimpinan kepala sekolah, biaya pendidikan, kualitas belajar mengajar guru sangat penting dalam mencapai tujuan pendidikan yang bermutu yang dapat menghasilkan lulusan yang bermutu pula. Oleh sebab itu, dalam penelitian ini akan dikaji lebih lanjut mengenai pengaruh kepemimpinan kepala sekolah dan biaya pendidikan terhadap kualitas proses belajar mengajar dan dampak selanjutnya dengan kompetensi lulusan.

\section{Metode Penelitian}

Penelitian ini merupakan penelitian survey dengan metode penelitian kuantitatif. Analisis dalam penelitian ini menggunakan analisis jalur (path analysis) yang dipakai untuk melukiskan dan menguji model hubungan antar variabel yang ber- bentuk sebab akibat (Sugiyono, 2016, p. 297). Penelitian dilaksanakan pada SMK di wilayah Kabupaten Gunungkidul yaitu (1) SMK Negeri 1 Wonosari, (2) SMK Negeri 2 Wonosari, (3) SMK Negeri 3 Wonosari, (4) SMK Negeri 1 Girisubo, (5) SMK Negeri Tepus, (6) SMK Muhammadiyah Semin, (7) SMK Teruna Jaya 1 Gunungkidul, (8) SMK Pembangunan Karangmojo, dan (9) SMK YAPPI Wonosari. Waktu penelitian adalah pada bulan Juli - Agustus 2018.

Populasi dalam penelitian ini adalah sembilan SMK di Kabupaten Gunungkidul yang berjumlah 462 orang yang dikelompokkan menurut kategori Rata-rata nilai Ujian Nasional (UN) SMK tahun 2017 di Kabupaten Gunungkidul. Teknik sampling yang digunakan dalam penelitian ini adalah proportionate stratified random sampling, sehingga diperoleh sampel sebanyak 210 guru mata pelajaran kelompok Normatif, Adaptif dan produktif.

Variabel pada penelitian ini terdiri dari variabel bebas (eksogen), variabel terikat (endogen) dan variabel perantaran (intervening). Variabel bebas yaitu kepemimpinan kepala sekolah $\left(X_{1}\right)$ dan biaya pendidikan $\left(\mathrm{X}_{2}\right)$; sedangkan variabel perantaranya adalah kualitas proses belajar mengajar $\left(\mathrm{X}_{3}\right)$ dan variabel terikatnya yaitu kompetensi lulusan $(\mathrm{Y})$.

Pengumpulan data dalam penelitian ini menggunakan kuesioner. Pengukuran kuesioner dalam penelitian ini menggunakan skala pengukuran Rating Scale. Kuesioner dibuat dalam bentuk pertanyaan tertutup, dimana responden diminta memilih salah satu jawaban kuantitatif yang berupa skor dari rentang angka 5, 4, 3, 2, 1 .

Angket diuji cobakan terlebih dahulu sebelum digunakan untuk pengambilan data dengan tujuan mengetahui validitas dan reliabilitas. Pengujian validitas dilakukan dengan validitas konstruk (construct validity). Pengujian validitas dapat dilakukan dengan menggunakan Korelasi Product Moment dari Pearson. Hasil uji validitas menunjukkan bahwa instrumen penelitian valid. Uji realibilitas instrumen kepada 30 responden untuk kepemimpinan kepala sekolah, biaya pendidikan, kualitas proses 
belajar mengajar dan kompetensi lulusan dengan teknik Alpha (Cronbach's). Hasil uji reliabel yaitu kepemimpinan kepala sekolah sebesar 0,949 , variabel biaya pendidikan sebesar 0,962, variabel kualitas proses belajar mengajar sebesar 0,934, dan variabel kompetensi lulusan sebesar 0,912, nilai $r$ Alpha Cronbach instrumen setiap variabel dalam penelitian ini lebih dari 0,60, artinya instrumen yang digunakan reliabel sehingga dapat mengukur variabel penelitian.

Data yang diperoleh dari lapangan selanjutnya akan dianalisis menggunakan analisis statistik yang terdiri dari analisis deskriptif dan analisis inferensial. Penelitian ini menggunakan statistik parametrik, sehingga harus dilakukan uji prasyarat an analisis. Uji prasyarat yang dilakukan meliputi: (1) Uji Normalities, (2) Uji Multikolinieritas, (3) Uji Heterokedastisitas dan (4) Uji Autokorelasi.

Teknik analisis data dalam penelitian ini menggunakan analisis regresi dan analisis jalur. Pengujian hipotesis dalam penelitian ini yaitu: Hipotesis pertama, kedua, ketiga, kesembilan dan kesepuluh diuji dengan teknik analisis jalur, hipotesis keempat sampai dengan kedelapan diuji dengan regresi sederhana. Persamaan garis regresi sederhananya dirumuskan sebagai berikut: $\mathrm{Y}=\mathrm{a}+\mathrm{bX}$ di mana $\mathrm{Y}=$ subyek dalam variabel independen yang diprediksikan (kompetensi lulusan dan kualitas proses belajar mengajar) $X=$ subyek pada variabel independen yang mempunyai nilai tertentu (kepemimpinan kepala sekolah dan biaya pendidikan).

Hipotesis kesebelas diuji dengan menggunakan regresi berganda (hubungan antara dua atau lebih variabel independen terhadap satu atau lebih variabel dependen). Analisis dilanjutkan dengan menghitung persamaan regresinya, untuk memprediksi seberapa tinggi nilai variabel dependen bila nilai variabel independen dimanipulasi. Persamaan garis regresi secara umum dirumuskan sebagai berikut: $Y=a+$ b1X1+ b2X2 dengan keterangan rumus: $\mathrm{Y}=$ kualitas proses belajar mengajar (variabel dependen); $\mathrm{X} 1=$ kepemimpinan kepala sekolah (variabel independen); $\mathrm{X} 2=$ biaya pendidikan (variabel independen); X3= disiplin kerja guru (variabel independen); $\mathrm{X} 4=$ budaya sekolah (variabel independen); $\mathrm{a}=$ konstanta; $\mathrm{b} 1, \mathrm{~b} 2$ = koefisien. regresi

Sedangkan untuk uji signifikansi konstanta dan setiap variabel independen dibangun Hipotesis sebagai berikut: $\mathrm{Ho}=$ Koefisien Regresi Tidak Signifikan $\mathrm{Ha}=$ Koefisien Regresi Signifikan

Pengambilan keputusan berdasarkan probabilitas, yaitu dengan cara melihat kolom signifikansi (Sig.) dan diperoleh hasil sebagai berikut: Jika Sig. $>0,05$ maka Ho diterima, Ha ditolak Jika Sig. < 0,05 maka Ho ditolak, Ha diterima.

\section{Hasil Penelitian dan Pembahasan}

\section{Deskripsi Hasil Penelitian}

Deskripsi data penelitian merupakan penyajian data hasil penelitian dari setiap variabel yaitu variabel Kepemimpinan Kepala Sekolah $\left(X_{1}\right)$, Biaya Pendidikan $\left(X_{2}\right)$, Kualitas Proses Belajar Mengajar $\left(X_{3}\right)$, dan Kompetensi Lulusan (Y).

Variabel kepemimpinan kepala sekolah dengan jumlah responden 210 diperoleh data skor maksimum 110 dan skor minimum 75. Skor variabel kepeminpinan kepala sekolah berdasarkan data yang dikumpulkan sebesar 20.758, sehingga dapat dihitung nilai kepemimpinan kepala sekolah sebesar $90 \%$.

Tabel 1. Distribusi Frekuensi

Kepemimpinan Kepala Sekolah

\begin{tabular}{cccc}
\hline No & Interval & Frekensi & Persentase (\%) \\
\hline 1 & $75-78$ & 1 & 0,48 \\
2 & $79-82$ & 2 & 0,95 \\
3 & $83-86$ & 13 & 6,19 \\
4 & $87-90$ & 28 & 13,33 \\
5 & $91-94$ & 26 & 12,38 \\
6 & $95-98$ & 27 & 12,86 \\
7 & $99-102$ & 29 & 13,81 \\
8 & $103-106$ & 29 & 13,81 \\
9 & $107-110$ & 55 & 26,19 \\
& Total & 210 & 100 \\
\hline
\end{tabular}

Kepemimpinan kepala sekolah di SMK Kabupaten Gunungkidul berada pada kategori sangat tinggi sebesar $44,8 \%$, kate- 
gori tinggi sebesar 27,6\%, kategori rendah sebesar $25,2 \%$ dan kategori sangat rendah sebesar 2,4\%. Kepemimpinan kepala sekolah dengan frekuensi di atas mean (rata-rata) sebesar $53,81 \%$ atau 113 responden. Sedangkan yang di bawah skor mean sebesar 46,19\% atau sebanyak 97 responden.

Variabel biaya pendidikan dengan jumlah responden 210 diperoleh data skor maksimum 90 dan skor minimum 59. Skor variabel biaya pendidikan berdasarkan data yang dikumpulkan sebesar 15.594, sehingga dapat dihitung nilai biaya pendidikan sebesar $83 \%$.

Tabel 2. Distribusi Frekuensi Biaya Pendidikan

\begin{tabular}{cccc}
\hline No & Interval & Frekensi & Persentasi (\%) \\
\hline 1 & $59-62$ & 5 & 2,38 \\
2 & $63-66$ & 14 & 6,67 \\
3 & $67-70$ & 21 & 10,00 \\
4 & $71-74$ & 104 & 49,52 \\
5 & $75-78$ & 22 & 10,48 \\
6 & $79-82$ & 13 & 6,19 \\
7 & $83-86$ & 10 & 4,76 \\
8 & $87-90$ & 21 & 10,00 \\
& Total & 210 & 100 \\
\hline
\end{tabular}

Biaya pendidikan di SMK Kabupaten Gunungkidul berada pada kategori sangat tinggi sebesar 14,8\%, kategori tinggi sebesar $16,7 \%$, kategori rendah sebesar $59,5 \%$ dan kategori sangat rendah sebesar 9,0\%. Biaya pendidikan dengan frekuensi di atas mean (rata-rata) sebesar 31,43\% atau 66 responden. Sedangkan yang dibawah skor mean sebesar $68,57 \%$ atau sebanyak 144 responden.

Variabel kualitas proses belajar mengajar dengan jumlah responden 210 diperoleh data skor maksimum 100 dan skor minimum 67. Skor variabel kualitas proses belajar mengajar berdasarkan data yang dikumpulkan sebesar 17.991, sehingga dapat dihitung nilai kualitas proses belajar mengajar sebesar $86 \%$.

Kualitas proses belajar mengajar di SMK Kabupaten Gunungkidul berada pada kategori rendah yaitu sebesar $37,6 \%$, kategori sangat tinggi sebesar 23,8\%, kategori tinggi sebesar $31,9 \%$ dan kategori sangat rendah sebesar $6,7 \%$. Kualitas proses bel- ajar mengajar dengan frekuensi di atas mean (rata-rata) sebesar $42,86 \%$ atau 90 responden. Sedangkan yang dibawah skor mean sebesar $56,19 \%$ atau sebanyak 120 responden.

Tabel 3. Distribusi Frekuensi Kualitas

Proses Belajar Mengajar

\begin{tabular}{cccc}
\hline No & Interval & Frekensi & Persentasi (\%) \\
\hline 1 & $67-70$ & 2 & $0,95 \%$ \\
2 & $71-74$ & 6 & $2,86 \%$ \\
3 & $75-78$ & 26 & $12,38 \%$ \\
4 & $79-82$ & 42 & $20,00 \%$ \\
5 & $83-86$ & 44 & $20,95 \%$ \\
6 & $87-90$ & 28 & $13,33 \%$ \\
7 & $91-94$ & 36 & $17,14 \%$ \\
8 & $95-98$ & 21 & $10,00 \%$ \\
9 & $99-102$ & 5 & $2,38 \%$ \\
& Total & 210 & 100 \\
\hline
\end{tabular}

Variabel kompetensi lulusan dengan jumlah responden 210 diperoleh data skor maksimum 97 dan skor minimum 67. Skor variabel kompetensi lulusan berdasarkan data yang dikumpulkan sebesar 16.695, sehingga dapat dihitung nilai kompetensi lulusan sebesar $80 \%$.

Tabel 4. Distribusi Frekuensi Kompetensi lulusan

\begin{tabular}{cccc}
\hline No & Interval & Frekensi & Persentasi (\%) \\
\hline 1 & $67-70$ & 6 & $2,86 \%$ \\
2 & $71-74$ & 20 & $9,52 \%$ \\
3 & $75-78$ & 59 & $28,10 \%$ \\
4 & $79-82$ & 85 & $40,48 \%$ \\
5 & $83-86$ & 25 & $11,90 \%$ \\
6 & $87-90$ & 4 & $1,90 \%$ \\
7 & $91-94$ & 6 & $2,86 \%$ \\
8 & $95-98$ & 5 & $2,38 \%$ \\
& Total & 210 & 100 \\
\hline
\end{tabular}

Kompetensi lulusan di SMK Kabupaten Gunungkidul berada pada kategori rendah yaitu sebesar $61,9 \%$. Kategori sangat tinggi sebesar 5,2\%, kategori tinggi sebesar $20,5 \%$ dan kategori sangat rendah sebesar $12,4 \%$.

Berdasarkan tabel distribusi frekuensi diketahui bahwa kompetensi lulusan dengan frekuensi di atas mean (rata-rata) sebesar $19,05 \%$ atau 40 responden. Sedangkan yang dibawah skor mean sebesar $80,95 \%$ atau sebanyak 170 responden. 
Sebelum uji hipotesis, terlebih dahulu dilakukan pengujian klasik atau uji prasyarat analisis regresi. Uji asumsi klasik terdiri dari uji normalitas, uji multikolineritas, uji heteroskedastisitas, dan uji autokorelasi. Berdasarkan hasil olah data Uji Normalitas dijelaskan bahwa nilai Asymp Sig. sebesar 0,108 atau $>0,05$. Sesuai dengan kaidah pengujian, maka dapat disimpulkan bahwa data berdistribusi normal. Hasil uji multikolinearitas menunjukkan bahwa setiap variabel memiliki nilai tolerance $>0,10$ dan nilai VIF < 10. Dengan demikian dapat disimpulkan bahwa antar variabel independen tidak terjadi hubungan multikolinearitas dalam model regresi.

Hasil uji heteroskedastisitas pada menunjukkan bahwa tidak ada variabel independen yang signifikan secara statistik mempengaruhi variabel dependen, dimana terlihat probabilitas signifikansinya di atas tingkat keyakinan 5\%. Jadi dapat disimpulkan bahwa model regresi tidak terjadi adanya heteroskedastisitas. Uji autokorelasi menggunakan uji Durbin-Watson (DW) menunjukkan bahwa nilai DW 1,630 artinya berada diantara -2 dan +2 , artinya tidak ada autokorelasi.

Hasil uji statistik untuk menjawab hipotesis pertama sampai dengan sebelas terangkum dalam Gambar 1, Tabel 5 dan Tabel 6.

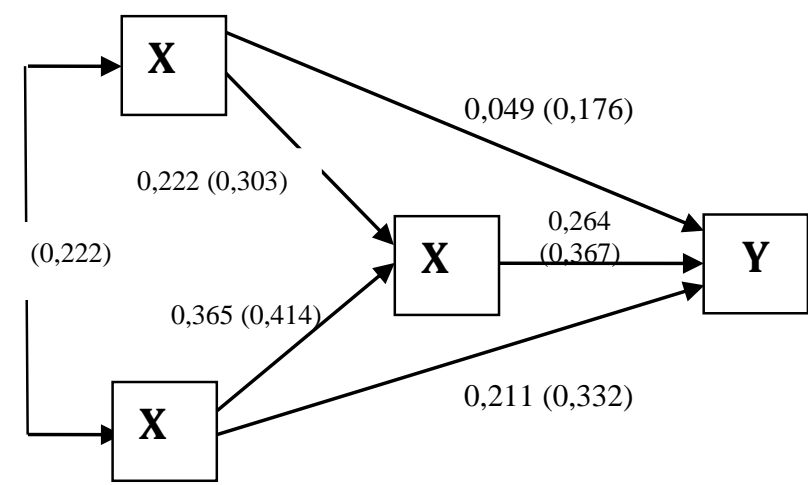

Gambar 1. Korelasi (R) Hasil Perhitungan antarvariabel (angka dalam kurung) dan Koefisien Jalur (angka di luar kurung)

Uji Hipotesis Pertama:

Berdasarkan hasil pada Gambar 1, Varibel-variabel yang mempengaruhi kom- petensi lulusan memiliki nilai $\mathrm{R}$ positif, artinya bahwa terdapat pengaruh yang positif variabel-variabel yang mempengaruhi kompetensi lulusan, sedangkan hasil koefisien jalur menunjukan ada satu koefisien jalur yang yaitu kepemimpinan kepala sekolah $\left(\mathrm{X}_{1}\right)$ terhadap kompetensi lulusan sebesar 0,049 artinya bahwa koefisien jalur tersebut kurang dari 0,05, maka jalur tersebut dapat diabaikan. Adanya salah satu koefisien jalur kurang dari 0,05, maka dapat disimpulkan bahwa hipotesis variabel-variabel yang berpengaruh terhadap kompetensi lulusan di SMK Kabupaten Gunungkidul tidak terbukti secara empiris.

\section{Uji Hipotesis Kedua}

Berdasarkan Tabel 5 dan Tabel 6 nilai korelasi (R) antara kepemimpinan kepala sekolah $\left(\mathrm{X}_{1}\right)$ dengan kompetensi lulusan $(\mathrm{Y})$ sebesar 0,176. Perhitungan koefisien jalur diperoleh hasil pengaruh langsung sebesar $0,049(<0,05)$, sedangkan pengaruh tidak langsung sebesar $0,059(>0,05)$ artinya variabel kepemimpinan kepala sekolah mempunyai pengaruh tidak langsung terhadap kompetensi lulusan $(\mathrm{Y})$, akan tetapi melalui korelasinya dengan kualitas proses belajar mengajar (X3) variabel kepemimpinan kepala sekolah mempengaruhi kompetensi lulusan, maka hipotesis terdapat pengaruh langsung dan tidak langsung kepemimpinan kepala sekolah terhadap kompetensi lulusan tidak diterima.

\section{Uji Hipotesis Ketiga}

Berdasarkan Tabel 5 dan Tabel 6 nilai korelasi (R) antara kepemimpinan kepala sekolah $\left(\mathrm{X}_{1}\right)$ dengan kompetensi lulusan $(\mathrm{Y})$ sebesar 0,332 , dan perhitungan koefisien jalur diperoleh nilai koefisiensi hasil korelasi langsung sebesar 0,211 (> 0,05), sedangkan korelasi tidak langsung sebesar 0,096 (> $0,05)$ artinya variabel biaya pendidikan mempunyai pengaruh langsung dan tidak langsung terhadap kompetensi lulusan (Y), maka hipotesis terdapat pengaruh langsung dan tidak langsung biaya pendidikan terhadap kompetensi lulusan diterima. 
Tabel 5. Sumbangan Efektif Variabel Eksogen (Langsung dan Tidak Langsung) terhadap Kompetensi Lulusan

\begin{tabular}{|c|c|c|c|}
\hline \multirow[b]{2}{*}{ Variabel } & \multicolumn{2}{|c|}{ Pengaruh Langsung dengan } & \multirow{2}{*}{$\begin{array}{c}\text { Pengaruh Tak Langsung } \\
\text { melalui } \\
\text { Kualitas Proses Belajar } \\
\text { Mengajar }\end{array}$} \\
\hline & $\begin{array}{l}\text { Kualitas Proses } \\
\text { Belajar Mengajar }\end{array}$ & $\begin{array}{l}\text { Kompetensi } \\
\text { Lulusan }\end{array}$ & \\
\hline Kepemimpinan Kepala Sekolah & $\begin{array}{c}0,222 \\
(22,2 \%)\end{array}$ & $\begin{array}{c}0,049 \\
(4,9 \%)\end{array}$ & $\begin{array}{c}0,222 \times 0,264=0,059 \\
(5,9 \%)\end{array}$ \\
\hline Biaya Pendidikan & $\begin{array}{c}0,365 \\
(36,5 \%)\end{array}$ & $\begin{array}{c}0,211 \\
(21,1 \%)\end{array}$ & $\begin{array}{c}0,365 \times 0,264=0,096 \\
(9,6 \%)\end{array}$ \\
\hline Kualitas Proses Belajar Mengajar & - & $\begin{array}{c}0,264 \\
(26,4 \%)\end{array}$ & - \\
\hline
\end{tabular}

Tabel 6. Rangkuman Hasil Regresi Sederhana

\begin{tabular}{|c|c|c|c|c|c|}
\hline \multicolumn{2}{|c|}{ Hubungan antarVariabel } & \multirow{2}{*}{$\begin{array}{c}\mathrm{R} \\
0,176\end{array}$} & \multirow{2}{*}{$\begin{array}{c}\text { Adjusted R } \\
\text { Square }\end{array}$} & \multirow{2}{*}{$\frac{t}{2,585}$} & \multirow{2}{*}{$\frac{\text { Sig. }}{0,010}$} \\
\hline $\begin{array}{l}\text { Kepemimpinan Kepala } \\
\text { Sekolah }\left(\mathrm{X}_{1}\right)\end{array}$ & Kompetensi Lulusan (Y) & & & & \\
\hline Biaya Pendidikan $\left(\mathrm{X}_{2}\right)$ & Kompetensi Lulusan (Y) & 0,332 & 0,106 & 5,073 & 0,000 \\
\hline $\begin{array}{l}\text { Kualitas Proses Belajar } \\
\text { Mengajar }\left(X_{3}\right)\end{array}$ & Kompeensi Lulusan (Y) & 0,367 & 0,130 & 5,688 & 0,000 \\
\hline $\begin{array}{l}\text { Kepemimpinan Kepala } \\
\text { Sekolah }\left(X_{3}\right)\end{array}$ & $\begin{array}{l}\text { Kualitas Proses Belajar } \\
\text { Mengajar }\left(X_{3}\right)\end{array}$ & 0,303 & 0,087 & 4,585 & 0,000 \\
\hline Biaya Pendidikan $\left(\mathrm{X}_{2}\right)$ & $\begin{array}{l}\text { Kualitas Proses Belajar } \\
\text { Mengajar }\left(X_{3}\right)\end{array}$ & 0,414 & 0,168 & 6,566 & 0,000 \\
\hline
\end{tabular}

\section{Uji Hipotesis Keempat}

Berdasarkan Tabel 6 hasil perhitungan koefisien korelasi (R) diperoleh 0,176 menunjukkan bahwa kepemimpinan kepala sekolah memiliki hubungan positif dan searah, sehingga apabila semakin tinggi nilai kepemimpinan kepala sekolah maka akan semakin tinggi pula nilai kompetensi lulusan. Besarnya Adjusted R Square adalah 0,026 yang artinya bahwa besarnya pengaruh kepemimpinan kepala sekolah terhadap kompetensi lulusan adalah 2,6\% sedangkan $97,4 \%(100 \%-2,6 \%)$ dipengaruhi oleh variabel lainnya yang tidak dimasukan dalam penelitian ini.

Variabel kepemimpinan kepala sekolah diperoleh $t_{\text {hitung }}$ sebesar 2,585, dan nilai signifikansi sebesar 0,010. Hasil perhitungan $t_{\text {tabel }}(t(0,05 ; 208)$ sebesar 1,971 . Karena nilai $t_{\text {hitung }}>t_{\text {tabel }}$ dan sig $<0,05$ maka diartikan bahwa variabel kepemimpinan kepala sekolah berpengaruh signifikan terhadap kompetensi lulusan. Dengan demikian dapat disimpulkan bahwa hipotesis keempat dapat diterima yaitu kepemimpinan kepala sekolah berpengaruh positif dan signifikan terhadap kompetensi lulusan di SMK Kabupaten Gunungkidul.

\section{Uji Hipotesis Kelima}

Berdasarkan Tabel 6 hasil perhitungan koefisien korelasi (R) diperoleh 0,332 menunjukkan bahwa biaya pendidikan memiliki hubungan positif dan searah, sehingga apabila semakin tinggi nilai biaya pendidikan maka akan semakint tinggi pula nilai kompetensi lulusan. Besarnya Adjusted R Square adalah 0,106 yang artinya bahwa besarnya pengaruh biaya pendidikan terhadap kompetensi lulusan adalah $10,6 \%$ sedangkan 89,4\% (100\% - 10,6\%) dipengaruhi oleh variabel lainnya yang tidak dimasukan dalam penelitian ini.

Variabel biaya pendidikan diperoleh $t_{\text {hitung }}$ sebesar 5,073, dan nilai signifikansi sebesar 0,000. Hasil perhitungan $t_{\text {tabel }}$ 
$(\mathfrak{t}(0,05 ; 208)$ sebesar 1,971. Karena nilai $t_{\text {hitung }}>t_{\text {tabel }}$ dan sig $<0,05$ maka diartikan bahwa variabel biaya pendidikan berpengaruh signifikan terhadap kompetensi lulusan. Dengan demikian dapat disimpulkan bahwa hipotesis kelima dapat diterima yaitu biaya pendidikan berpengaruh positif dan signifikan terhadap kompetensi lulusan di SMK Kabupaten Gunungkidul.

\section{Uji Hipotesis Keenam}

Berdasarkan Tabel 6 hasil perhitungan koefisien korelasi (R) diperoleh 0,367 menunjukkan bahwa kualitas proses belajar mengajar memiliki hubungan positif dan searah, sehingga apabila semakin tinggi nilai kualitas proses belajar mengajar maka akan semakint tinggi pula nilai kompetensi lulusan. Besarnya Adjusted R Square adalah 0,130 yang artinya bahwa pengaruh kualitas proses belajar mengajar terhadap kompetensi lulusan adalah $13,0 \%$ sedangkan $87,0 \%$ (100\%-13,0\%) dipengaruhi oleh variabel lainnya yang tidak dimasukan dalam penelitian ini.

Variabel kualitas proses belajar mengajar diperoleh thitung sebesar 6,688 dan nilai signifikansi sebesar 0,000. Hasil perhitungan $t_{\text {tabel }}(t(0,05 ; 208)$ sebesar 1,971 . Karena nilai $t_{\text {hitung }}>t_{\text {tabel }}$ dan sig $<0,05$ maka diartikan bahwa variabel kualitas proses belajar mengajar berpengaruh signifikan terhadap kompetensi lulusan. Dengan demikian dapat disimpulkan bahwa hipotesis keenam dapat diterima yaitu kualitas prosses belajar mengajar berpengaruh positif dan signifikan terhadap kompetensi lulusan di SMK Kabupaten Gunungkidul.

\section{Uji Hipotesis Ketujuh}

Berdasarkan Tabel 6 hasil perhitungan koefisen korelasi (R) diperoleh 0,303 menunjukkan bahwa kepemimpinan kepala sekolah memiliki hubungan positif dan searah, sehingga apabila semakin tinggi nilai kepemimpinan kepala sekolah maka akan semakint tinggi pula nilai kualitas proses belajar mengajar. Besarnya Adjusted R Square adalah 0,087 yang artinya bahwa besarnya pengaruh kepemimpinan kepala sekolah terhadap kualitas proses belajar mengajar adalah 8,7\% sedangkan 91,3\% (100\%-8,7\%) dipengaruhi oleh variabel lainnya yang tidak dimasukan dalam penelitian ini.

Variabel kualitas proses belajar mengajar diperoleh $t_{\text {hitung }}$ sebesar 4,585 dan nilai signifikansi sebesar 0,000. Hasil perhitungan $t_{\text {tabel }}(t(0,05 ; 208)$ sebesar 1,971 . Karena nilai $t_{\text {hitung }}>t_{\text {tabel }}$ dan sig $<0,05$ maka diartikan bahwa variabel kepemimpinan kepala sekolah berpengaruh signifikan terhadap kualitas proses belajar mengajar. Dengan demikian dapat disimpulkan bahwa hipotesis ketujuh dapat diterima yaitu kepemimpinan kepala sekolah berpengaruh positif dan signifikan terhadap kualitas proses belajar mengajar di SMK Kabupaten Gunungkidul.

\section{Uji Hipotesis Kedelapan}

Berdasarkan Tabel 6 hasil perhitungan koefisen korelasi (R) diperoleh 0,414 menunjukkan bahwa biaya pendidikan memiliki hubungan positif dan searah, sehingga apabila semakin tinggi nilai biaya pendidikan maka akan semakint tinggi pula nilai kualitas proses belajar mengajar. Besarnya Adjusted R Square adalah 0,168 yang artinya bahwa pengaruh biaya pendidikan terhadap kualitas proses belajar mengajar adalah 16,8\% sedangkan 83,2\% (100\%-16,8\%) dipengaruhi oleh variabel lainnya yang tidak dimasukan dalam penelitian ini.

Variabel kualitas proses belajar mengajar diperoleh $t_{\text {hitung }}$ sebesar 6,566 dan nilai signifikansi sebesar 0,000. Hasil perhitungan $t_{\text {tabel }}(t(0,05 ; 208)$ sebesar 1,971 . Karena nilai $t_{\text {hitung }}>t_{\text {tabel }}$ dan sig $<0,05$ maka diartikan bahwa variabel biaya pendidikan berpengaruh signifikan terhadap kualitas proses belajar mengajar. Dengan demikian dapat disimpulkan bahwa hipotesis kedelapan dapat diterima yaitu biaya pendidikan berpengaruh positif dan signifikan terhadap kualitas proses belajar mengajar di SMK Kabupaten Gunungkidul.

\section{Uji Hipotesis Kesembilan}

Berdasarkan Gambar 1 dan Tabel 5 hasil perhitungan koefisien jalur $X_{1}$ terhadap $X_{3}$ sebesar 0,222 (positif) dengan nilai $p$ (sig) sebesar 0,001 (signifikan), sedangkan 
nilai koefisien jalur antara X3 den $\mathrm{Y}$ sebesar 0,264 (positif) dengan nilai $p$ (sig) sebesar 0,000 (signifikan). Besarnya pengaruh kepemimpinan kepala sekolah $\left(X_{1}\right)$ terhadap kompetensi lulusan (Y) melalui kualitas proses belajar mengajar $\left(X_{3}\right)$ sebesar $5,9 \%$. Oleh karena besarnya nilai $X_{1}$ terhadap $Y$ melalui $X_{3}$ lebih besar dari 0,05, serta memberikan pengaruh positif dan signifikan, sehingga hipotesis diterima yaitu terdapat pengaruh positif dan signifikan kepemimpinan kepala sekolah terhadap kompetensi lulusan melalui kualitas proses belajar mengajar.

\section{Uji Hipotesis Kesepuluh}

Berdasarkan Gambar 1 dan Tabel 5 hasil perhitungan koefisien jalur $X_{2}$ terhadap $X_{3}$ sebesar 0,365 (positif) dan nilai $p$ (sig) sebesar 0,000 (signifikan), sedangkan nilai koefisien jalur antara $\mathrm{X}_{3}$ den $\mathrm{Y}$ sebesar 0,264 . (positif) dengan nilai $p$ (sig) sebesar 0,000 (signifikan). Besarnya pengaruh biaya pendidikan $\left(\mathrm{X}_{2}\right)$ terhadap kompetensi lulusan (Y) melalui kualitas proses belajar mengajar $\left(X_{3}\right)$ sebesar $9,6 \%$. Oleh karena besarnya nilai $\mathrm{X}_{2}$ terhadap $\mathrm{Y}$ melalui $\mathrm{X}_{3}$ lebih besar dari 0,05 , serta memberikan pengaruh positif dan signifikan, sehingga hipotesis diterima yaitu terdapat pengaruh positif dan signifikan biaya pendidikan terhadap kompetensi lulusan melalui kualitas proses belajar mengajar.

\section{Uji Hipotesis Kesebelas}

Perhitungan regresi ganda diperoleh hasil koefisen korelasi (R) sebesar 0,467 menunjukkan bahwa kepemimpinan kepala sekolah dan biaya pendidikan memiliki hubungan positif dan searah, sehingga apabila semakin tinggi nilai kepemimpinan kepala sekolah dan biaya pendidikan maka akan semakint tinggi pula nilai kualitas proses belajar mengajar. Besarnya Adjusted R Square adalah 0,211 yang artinya bahwa pengaruh kepemimpinan kepala sekolah dan biaya pendidikan terhadap kualitas proses belajar mengajar adalah 21,1 \% sedangkan $78,9 \% \quad(100 \%-21,1 \%)$ dipengaruhi oleh variabel lainnya yang tidak dimasukan dalam penelitian ini.
Variabel kepemimpinan kepala sekolah dan biaya pendidikan secara besamasama diperoleh $t_{\text {hitung }}$ sebesar 6,225 dan nilai signifikansi sebesar 0,000. Hasil perhitungan $t_{\text {tabel }}(t(0,05 ; 207)$ sebesar 1,971 . Karena nilai $t_{\text {hitung }}>t_{\text {tabel }}$ dan sig $<0,05$ maka diartikan bahwa variabel kepemimpinan kepala sekolah dan biaya pendidikan secara bersamasama berpengaruh signifikan terhadap kualitas proses belajar mengajar.

Hasil uji $F_{\text {hitung sebesar 28,929, dan sig }}$ 0,000, sedangkan $F_{\text {tabel }}$ yaitu $F(2)(210-2-1)$ sebesar 3,039. Hasil analisis diperoleh $F_{\text {hitung }}>$ $\mathrm{F}_{\text {tabel, }}(28,929>3,039)$ atau nilai $\mathrm{p}<\alpha(0,00<$ $0,05)$, maka Hipotesis diterima yaitu terdapat pengaruh positif dan signifikan kepemimpinan kepala sekolah dan biaya pendidikan secara bersama-sama terhadap kualitas proses belajar mengajar di SMK Kabupaten Gunungkidul.

\section{Pembahasan}

Menguji Structural Hubungan antara Variabel yang Mempengaruhi Kompetensi Lulusan secara Empiris.

Berdasarkan temuan pada Gambar 1 koefisien jalur varibel kepemimpinan kepala sekolah $\left(\mathrm{X}_{1}\right)$ terhadap kompetensi lulusan (Y) kurang dari 0,05 $(0,049<0,05)$, maka jalur langsung kepemimpinan kepala sekolah $\left(\mathrm{X}_{1}\right)$ terhadap kompetensi lulusan $(\mathrm{Y})$ dapat diabaikan, sehingga diagram jalur yang lama digantikan dengan diagram jalur yang baru seperti pada Gambar 2.

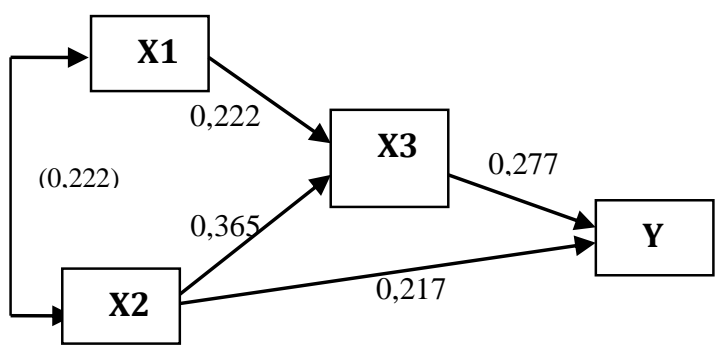

Gambar 2. Diagram Baru Perubahan dari Gambar 1 setelah Koefisien jalur $\mathrm{p}_{41}$ Tidak Diperhitungkan

Berdasarkan hasil pengujian dengan berubahnya jalur yaitu dengan menghitung koefisien jalur baru dan hasil pengujian matrik korelasi yang baru, maka hipotesis pertama tidak diterima bahwa semua varia- 
bel-variabel yang berpengaruh terhadap kompetensi lulusan di SMK Kabupaten Gunungkidul tidak terbukti secara empiris.

Pengaruh Langsung atau Tidak Langsung Kepemimpinan Kepala Sekolah terhadap Kompetensi Lulusan

Hasil pengujian dengan analisis jalur diperolehh hasil bahwa kepemimpinan kepala sekolah tidak mempunyai pengaruh secara langsung dengan kompetensi lulusan tetapi mempunyai pengaruh langsung terhadap kompetensi lulusan melalui kualitas proses belajar mengajar, meskipun kontribusinya rendah yaitu sebesar $12,7 \%$ ' Hal ini menunjukkan bahwa kepemimpinan kepala sekolah tidak dapat menjelaskan pengaruhnya terhadap kompetensi lulusan. Kepala sekolah sebagai penentu kebijakan mempunyai peran langsung dalam mempengaruhi dan menggerakkan komponen sekolah dalam menjalankan program-program sekolah diantaranya proses belajar mengajar, sehingga hasil dari program yang telah dilaksanakan dapat memberikan pengaruh yang signifikan terhadap kompetnsi lulusan. Berdasarkan hasil tersebut hipotesis yang diajukan tidak diterima, artinya tidak terdapat pengaruh langsung dan terdapat pengaruh tidak langsung antara kepemimpinan kepala sekolah dengan kompetensi lulusan SMK di Kabupaten Gunungkidul.

Pengaruh Langsung atau Tidak Langsung Biaya Pendidikan terhadap Kompetensi Lulusan

Hasil pengujian nilai koefisien jalur di atas menujukkan bahwa terdapat pengaruh langsung biaya pendidikan terhadap kompetensi lulusan dengan kontribusi sebesar $21,1 \%$. Hal ini menunjukkan bahwa pengaruh yang terjadi antara biaya pendidikan dengan kompetensi lulusan adalah pengaruh positif. Pengaruh biaya pendidikan terhadap kompetensi lulusan menunjukkan pengaruh yang lebih besar dibandingkan dengan pengaruhnya melalui kualitas proses belajar mengajar yang hasilnya sebesar $9,6 \%$. Hal ini meunjukkan bahwa biaya pendidikan di SMK Kabupaten Gunungkidul merupakan komponen yang sangat mendukung berjalannya suatu program dalam mencapai kompeensi lulusan sesuai standar yang ditentukan. Hasil temuan di atas sesuai dengan hipotesis bahwa "terdapat pengaruh langsung dan tidak langsung antara biaya pendidikan dengan kompetensi lulusan di SMK Kabupaten Gunungkidul.

Pengaruh Kepemimpinan Kepala Sekolah (X1) terhadap Kompetensi Lulusan (Y).

Penjelasan hasil di atas menunjukkan bahwa kepemimpinan kepala sekolah memiliki pengaruh yang sangat rendah terhadap kompetensi lulusan yaitu sebesar 2,6\%. Sangat rendahnya pengaruh kepemimpinan kepala sekolah terhadap kompetensi lulusan diduga karena kepemimpinan kepala sekolah tidak dapat memberikan efek langsung tehadap kopetesi lulusan.Hal ini terbukti dengan hasil pada uji hipotesis kedua yang menyatakan bahwa kepemimpinan kepala sekolah tidak mempunyai pengaruh langsung dengan kompetensi lulusan, tetapi sebaliknya mempunyai pengaruh tidak langsung. Hal ini menunjukkan bahwa kepemimpinan kepala sekolah di SMK Kabupaten Gunungkidul tidak dapat menjelaskan pengaruhnya terhadap kompetensi lulusan.

Berdasarkan pengamatan peneliti proses supervisi yang dilakukan sekolah kurang maksimal sehingga dampak dari proses tersebut kurang sesuai yang diharapkan yang pada akhirnya hasil dari berjalannya proses yaitu kompetensi yang dimiliki lulusan belum bisa terlihat dengan baik. Hal ini yang menyebabkan kepemimpinan kepala sekolah memberikan sumbangan yang sangat rendah terhadap kompetensi lulusan. Berdasarkan uraian tersebut hipotesis yang menyatakan pengaruh kepemimpinan kepala sekolah terhadap kompetensi lulusan di SMK Kabupaten Gunungkidul dapat diterima.

Pengaruh Biaya Pendidikan (X2) terhadap Kompetensi Lulusan (Y)

Biaya pendidikan memiliki pengaruh terhadap kompetensi lulusan meskipun pengaruhnya tidak cukup besar yaitu sebesar $10,6 \%$. Hal ini sesuai dengan penelitian 
Togatorup (2017) yang menyatakan bahwa biaya pendidikan berpengaruh secara langsung positif terhadap mutu sekolah. Kompetensi lulusan merupakan bagian dari mutu sekolah, karena kompetensi lulusan merupakan bentuk output dari penyelenggaraan pendidikan. Berdasarkan hasil uji di atas biaya pendidikan memiliki pengaruh yang tidak cukup besar terhadap kompetensi lulusan. Meskipun pengaruh yang diberikan biaya pendidikan terhadap kompetensi merupakan sumber daya untuk mencapai tujuan pendidikan yang bermutu. Oleh karena itu tidak hanya jumlah biaya yang dibutuhkan tetapi juga diperlukan model pendanaan secara efektif dan efisien serta pengalokasian yang tepat.Hal ini menunjukkan bahwa pernyataan hipotesis terdapat pengaruh biaya pendidikan terhadap kompetensi lulusan pada SMK di Kabupaten Gunungkidul dapat diterima.

Pengaruh Kualitas Proses Belajar Mengajar (X3) terhadap Kompetensi Lulusan (Y).

Kualitas proses belajar mengajar memberikan pengaruh yang positif terhadap kompetensi lulusan sebesar 13\%. Tujuan dalam pembelajaran adalah adanya perubahan tingkah laku siswa setelah mengikuti. Hal ini sesuai dengan pendapat dari Hoy \& Miskel (2008, p. 43) dimana dijelaskan bahwa pembelajaran akan terjadi dimana pengalaman dapat menghasilkan perubahan pada pengetahuan atau perilaku. Perubahan dalam pengetahuan atau perilaku merupakan bagian dari kompetensi yang menjadi bekal siswa setelah mengikuti pembelajaran. Oleh karena proses belajar mengajar yang berkualitas sebagai penentu dalam menghasilkan perubahan. Oleh sebab itu, maka pernyataan hipotesis terdapat pengaruh kualitas proses belajar mengajar terhadap kompetensi lulusan pada SMK di Kabupaten Gunungkidul dapat diterima.

Pengaruh Kepemimpinan Kepala Sekolah (X1) terhadap Kualitas Proses Belajar Mengajar (X3)

Kepemimpinan kepala sekolah terhadap kualitas proses belajar mengajar memberikan pengaruh yang positif sebesar $8,7 \%$, hal ini menunjukkan bahwa kontribusi tersebut tergolong rendah. Dengan melihat adanya korelasi yang positif antara kepemimpinan kepala sekolah dengan kualitas proses belajar mengajar, maka dapat diartikan bahwa makin tinggi kepemimpinan kepala sekolah makin tinggi kualitas proses belajar mengajar. Oleh karena itu SMK di Kabupaten Gunungkidul harus berupaya menentukan kepemimpinan kepala sekolah pada komponen mana yang masih perlu ditingkatkan untuk dapat mendorong peningkatan kualitas proses belajar mengajar. Berdasarkan hasil penelitian komponen supervisi pendidikan pada kepemimpinan kepala sekolah yang perlu adanya peningkatan dalam pelaksanaannya. Supervisi pembelajaran akan mengontrol kesiapan guru, proses pelaksanaan, dan tindak lanjut proses pembelajaran yang telah dilakukan oleh guru, sehingga dapat diketahui kekurangan guru dalam proses belajar mengajar yang selanjutnya dapat digunakan oleh kepala sekolah untuk menentukan strategi dalam peningkatan kualitas guru dalam proses pembelajaran. Oleh sebab itu maka pernyataan hipotesis terdapat pengaruh kepemimpinan kepala sekolah terhadap kualitas proses belajar mengajar pada SMK di Kabupaten Gunungkidul dapat diterima.

Pengaruh Biaya Pendidikan (X2) terhadap Kualitas Proses Belajar Mengajar (X3)

Biaya pendidikan terhadap kualitas proses belajar mengajar memberikan pengaruh yang positif sebesar $16,8 \%$, hal ini menunjukkan bahwa kontribusi tersebutcukup besar. Dengan melihat adanya korelasi yang positif antara biaya pendidikan dengan kualitas proses belajar mengajar, maka dapat diartikan bahwa makin tinggi biaya pendidikan makin tinggi kualitas proses belajar mengajar. Pernyataan hipotesis terdapat pengaruh biaya pendidikan terhadap kualitas proses belajar mengajar pada SMK di Kabupaten Gunungkidul dapat diterima.

Pengaruh Kepemimpinan Kepala Sekolah (X1) terhadap Kompetensi Lulusan (Y) melalui Kualitas Proses Belajar Mengajar (X3)

Kualitas proses belajar mengajar merupakan variabel intervening hubungan 
antara kepemimpinan kepala sekolah dengan kompetensi lulusan dengan koefisen jalur $p>0,05$. Kepala Sekolah merupakan suatu faktor yang terpenting dalam proses pencapaian, keberhasilan sekolah dalam pencapaian tujuannya. Dengan demikian Kepala Sekolah sangat diharapkan pengaruhnya untuk mengendalikan agar pendidikan berjalan sesuai harapan semua pihak. Dalam menjalankan fungsinya Kepala Sekolah sebagai pemimpin pendidikan harus dapat menciptakan situasi belajar mengajar sehingga guru-guru dapat melaksanakan pengajarannya dan siswa-siswa dapat belajar. Pernyataan hipotesis terdapat pengaruh kepemimpinan kepala sekolah terhadap kompetensi lulusan melalui kualitas proses belajar mengajar pada SMK di Kabupaten Gunungkidul dapat diterima.

Pengaruh Biaya Pendidikan (X2) terhadap Kompetensi Lulusan (Y) melalui Kualitas Proses Belajar Mengajar (X3).

Kualitas proses belajar mengajar merupakan variabel intervening hubungan antara biaya pendidikan dengan kompetensi lulusan dengan nilai koefisien jalur $p>0,05$. Proses pendidikan dalam hal ini lebih pada proses belajar mengajar merupakan salah satu proses dalam rangka mencapai output sesuai tujuan pendiidkan. Untuk berjalannya proses tersebut sangat diperlukan adanya dukungan biaya. Pernyataan hipotesis terdapat pengaruh biaya pendidikan terhadap kompetensi lulusan melalui kualitas proses belajar mengajar pada SMK di Kabupaten Gunungkidul dapat diterima.

Pengaruh Kepemimpinan Kepala Sekolah (X1) dan Biaya Pendidikan (X2) secara Bersamasama terhadap Kualitas Proses Belajar Mengajar (X3)

Apabila proses belajar mengajar didukung dengan kepemimpinan kepala sekolah yang baik dan biaya pendidikan yang memadahi maka proses belajar mengajar akan memiliki kualitas sebesar 21,1\%. Adapun sumbangan efektif untuk setiap variabel yaitu kepemimpinan kepala sekolah $8,7 \%$ dan variabel biaya pendidikan $16,8 \%$. Pernyataan hipotesis terdapat pengaruh kepemimpinan kepala sekolah dan biaya pendidikan secara bersama-sama terhadap kualitas proses belajar mengajar pada SMK di Kabupaten Gunungkidul dapat diterima.

\section{Simpulan}

Berdasarkan hasil analisis penelitian dan pembahasan dapat diambil kesimpulan sebagai berikut:

Pertama, kepemimpinan kepala sekolah, biaya pendidikan, kualitas proses belajar mengajar dan kompetensi lulusan di SMK Kabupaten Gunungkidul termasuk kategori tinggi. Kedua, struktur pengaruh antar variabel yang mempengaruhi kompetensi lulusan di SMK Kabupaten Gunungkidul tidak terbukti secara empiris.

Ketiga, tidak terdapat pengaruh langsung dan terdapat pengaruh langsung kepemimpinan kepala sekolah terhadap kompetensi lulusan di SMK Kabupaten Gunungkidul. Keempat, terdapat pengaruh langsung dan tidak langsung biaya pendidikan terhadap kompetensi lulusan di SMK Kabupaten Gunungkidul.

Kelima, terdapat pengaruh kepemimpinan kepala sekolah, biaya pendidikan dan kualitas proses belajar mengajar secara terhadap kompetensi lulusan di SMK Kabupaten Gunungkidul. Keenam, terdapat pengaruh kepemimpinan kepala sekolah dan biaya pendidikan terhadap kualitas proses belajar mengajar di SMK Kabupaten Gunungkidul

Beberapa saran yang direkomendasikan yaitu sebagai berikut.

Guru lebih profesional dalam meningkatkan pelaksanaan tugas dan tanggung jawabnya. Guru secara berkelanjutan berusaha meningkatkan pengetahuannya dalam menerapkan prinsip pembelajaran yang benar yang mendorong siswa pada perilaku belajar efektif.

Guru perlu meningkatkan pengetahuannya dalam menggunakan sarana prasarana yang mendukung proses belajar mengajar. Selain itu Guru juga perlu meningkatkan perannya sebagai pemimpin pembelajaran yaitu dengan cara meningkatkan supervisi pembelajaran dan juga mengem- 
bangkan kurikulum sesuai dengan tuntutan dunia usaha dan dunia industri dengan cara menjalin mintra dengan industri, serta mengembangkan sumber daya manusia yang ada untuk secara bersama-sama dapat mewujudkan sekolah yang bermutu dengan menghasilkan siswa yang yang memiliki kompetensi yang diunggulkan terutama dalam hal sikap dan pengetahuan.

Bagi sekolah dapat meningkatkan pengelolaan biaya pendidikan dengan prinsip ketercukupan, efektif dan efisien, Kepada peneliti untuk melakukan penelitian lanjutan dengan lebih mengkaji faktor-faktor lain yang mempengaruhi kompetensi lulusan sehingga dapat menambah wawasan yang luas.

\section{DAFTAR PUSTAKA}

Badan Pusat Statistik. (2018). Berita resmi statistik. Jakarta: BPS Indonesia.

Damhuri, E. (2017, October 19). Kunci sukses pembangunan. Republika.Co.Id. Retrieved from https://www.republika.co.id/berita/j urnalisme-warga/wacana/ 17/10/19/ oy13jn440-kunci-suksespembangunan

Fadhilah, U. N., \& Hermawan, B. (2017, May 3). Ini tujuh masalah pendidikan di Indonesia menurut JPPI. Republika.Co.Id. Retrieved from https://www.republika.co.id/berita/ pendidikan/eduaction/17/05/03/opc hjr354-ini-tujuh-masalah-pendidikandi-indonesia-menurut-jppi

Hoy, W. K., \& Miskel, C. G. (2008).

Edicational administration. New York:
McGraw Hill Company.

Martin, \& Fuad, N. (2014). Manajemen pembiayaan pendidikan: konsep dan aplikasinya. Jakarta: PT Raja Grafindo Persada.

Presiden Republik Indonesia. UndangUndang Republik Indonesia nomor 20 tahun 2003 tentang Sistem Pendidikan Nasional (2003). Indonesia.

Priansa, D. J. (2014). Kinerja dan profesionalisme guru. Bandung: Alfabeta.

Putri, T. (2018, January 19). Ada apa dengan pendidikan di Indonesia? Edukasi. Retrieved from https:/ / student.cnnindonesia.com/ed ukasi/20180103112420-445266335/ada-apa-dengan-pendidikandi-indonesia/

Sugiyono. (2016). Statistika untuk penelitian. Bandung: Alfabeta.

Togatorup, M. (2017). Pengaruh biaya pendidikan terhadap mutu sekolah SMA swasta. Jurnal Pendidikan Dan Kebudayaan, 7(3).

United Nations Development Programme. (2015). Human development report 2015. Retrieved from http://hdr.undp.org/sites/default/fil es/2015_human_development_report. pdf

Wahyudin, D. H. (2014). Manajemen kurikulum. Bandung: PT. Remaja Rosda Karya. 